\title{
Jesus' father: The quest for the historical Joseph
}

\author{
Andries van Aarde \\ Department of New Testament Studies (Sec A) \\ University of Pretoria
}

\begin{abstract}
This article aims at demonstrating the historical probability that Joseph, the father of Jesus, should be regarded as a legendary figure. It seems that the Joseph figure is modeled after the patriarch in the First Testament. Here Joseph was exalted despite of slander. He married an 'impure' virgin. He became the adversary of Judah. His sons, born in Egypt, were seen as the forefathers of the illegitimate Samaritans. He was regarded as an ethical paradigm. He served as the ideal type for God's beloved child. The search for the historical Joseph leads to the conclusion that Jesus grew up fatherless.' This conclusion has enormous consequences for the quest for the historical Jesus.
\end{abstract}

\section{JOSEPH THE CARPENTER}

The idiom like father like son does not often point to a reality, but in Mediterranean culture, at least, it is a common ideal. In this regard we have in the Gospel of John (5:17) a Jesus saying, undoubtedly not authentic, that he is at work as his father is at work. In the Johannine context this saying refers to deeds of healing and compassion and a relationship between Jesus and God as his father. The context also involves the outrage of the Pharisees that Jesus could dare to see himself as child of God.

F C Grant (1956:96-114), the great biblical historian of a previous generation, valued this Johannine phrase as a probable indication that the son Jesus stands in the shoes of his father Joseph. Jesus is a carpenter, like his father, but typical to Johannine style the author of the Fourth Gospel draws an analogy between the physical son-father relationship and the spiritual relationship between Jesus and his heavenly Father ${ }^{1}$.

* Paper presented at the annual meeting of the New Testament Society of South Africa, Pretoria, April 14-17, 1998. The paper is based on a reworked edition of a chapter (entitled 'The Joseph trajecory') in the author's coming book Fatherless in Galilee: The search for Jesus child of God. The article is dedicated to Eddie Engelbrecht, Professor Emeritus, Hervormde Teologiese Opleiding, Klipdrif, South Africa. 
Thus, it is quite possible to understand the relationship between Jesus and Joseph in this manner, according to the interpretation in the Fourth Gospel. However, I cannot see how the relationship between Jesus and his heavenly Father could be analogous to the 'working' of father and son (Jn 5:17) in the sense of their mutual craftmanship. Nowhere in the Gospel of John do we find an indication that the Johannine school knows or makes use of the Markan tradition (6:3) that Jesus himself was a carpenter. We know that this tradition was changed by Matthew (13:55) to be read as 'the carpenter's son'. Luke simply ignores Mark's notation of Jesus (or Joseph) being a carpenter in the particular passage. Luke proffers only the question: 'Isn't this Joseph's son?' (Lk 4:22.)

Apocryphal gospels, like the second-century Proto-James and documents and fragments thereof, for example The Life of Joseph the Carpenter and Pseudo-Matthew, took over the Matthean hunch that Joseph was a carpenter but without elaborating on this mien as such. These documents were written (maybe translated into either dialects of the Greco-Egyptian language Coptic or Latin) during the period from the end of the fourth century till the six century. They only mention:

* Joseph's righteousness;

* . his old age;

* the death of his wife while his youngest son James was still a child;

* the names of other siblings (taken over from evidence in the New Testament itself);

* that Joseph was of old age (eighty nine years) when he took Mary as wife, though he never slept with her, and that he lived to the age of one hundred and eleven ${ }^{2}$.

Regardless of the fact that the title of the fifth-century document The Life of Joseph the Carpenter bears witness to the notation, found only in the first century in the Gospel of Matthew, that Joseph the carpenter adopted Jesus as his son, the alluded analogy between father and son in this text does not concern craftmanship or even Jesus' relationship with Joseph. What we actually find is a similarity between Joseph the widower who took the pregnant Mary into his house and Joseph the First Testament patriarch (see Manns 1977:82, 87). The equivalent to the parallel of the two Josephs is the parallel between the character of Mary and that of the First Testament Hannah (1 Sam [LXX] 1:11). The Mary-Hannah parallel is found in Proto-James and the abovementioned dependent apocryphal documents. 


\section{JOSEPH THE PATRIARCH}

Also in the Coptic Arabic version of The Life of Joseph the Carpenter (chapter 7) (Manns 1977:87) the correspondences between father and son pertain to geographical issues. Characteristic of Mediterranean mores the residential cite of a family/clan is located at the burial place of the founder of the group. The tomb in turn is the place where a future leader is expected to be born. This leader will continue the works of the forefather. In The Life of Joseph the Carpenter the tradition is that Jesus was born in Bethlehem as it is the case in those gospels in the New Testament where this tradition is also taken up (Mt 2:6; Lk 2:4; Jn 6:41; 7:27, 41). In all these instances the relationship between Jesus of Nazareth and Joseph whose ancestors are claimed to be from Bethlehem is in focus.

This particular tradition, explicit in Matthew and implicit in Luke and John, originated in the prophetic witness (Micah 5:2) against the supposedly mighty Judean royalty in favor of an allegedly inferior ruler whose roots are from the northern tribes: 'But you, Bethlehem, in the land of Judah, are by no means least among the rulers of Judah: for out of you will come a ruler who will be the shepherd of my people Israel' (Micah 5:2, in Mt 2:6). The prophetic voice in Micah 2-5 was raised against the lack of righteousness among the elites in Jerusalem. Bethlehem (i.e. Ephrat - see Gen 48:7) was the burial place of Rachel, wife of Jacob and mother of Joseph and Benjamin. The prophet Jeremiah (31:15) speaks of Rachel weeping about her lost descendants. Matthew (2:17-18) also quotes this passage over against the good tidings that the child Jesus outlived the onslaught of the 'king' in Judea (Herod the Great), only to be killed at thirty in Jerusalem because he was believed to be the 'newborn king'.

Round about the middle of the eight century B C E the dominant belief in Israel was that Israel is God's covenantal people and that the cultic shrine at Bethel was the visible guarantee that Israel would continue to exist as kingdom (see inter alia Amos 7:10-13) ${ }^{3}$. Among the evidence in the Pentateuchal traditions, Deuteronomy 33:13-17 and Genesis 37:1-11 witness to the belief that Joseph is the legitimate successor of his father Jacob and not Judah. According to this tradition the site to which God's people were cultically attached was Bethel, also called Luz (Gen 28:19; 35:6). At Bethel heaven and earth met as God entered into a covenant with Jacob and Jacob's children. Here, on the road between Bethel and Bethlehem (Ephrath) Rachel died and was buried (Gen 35:19). At the time of the centralization of the cult in Jerusalem earnest attempts were made to disfavor and even to destroy the Bethel tradition (see Hos 1:4-5).

During the Second Jerusalem Temple period a final onset was made on the Bethel tradition. The destruction of Samaria, capital of the northern kingdom since the reign

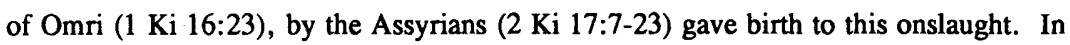


the re-established Judean kingdom, after the Babylonian exile, the conviction was nurtured that the Israelites of the northern kingdom were actually replaced by outsiders ( 2 Ki 17:24-26). The northerners were now labeled 'the Samaritans' (see Montgomery [1907] 1968:49). For the Judeans Jerusalem became the uncontested 'city of David'. What both David and Solomon intended to be an act of peacemaking became an ideological instrument par excellence both during the First Temple period and specifically the Second Temple period to marginalize and silence opposition. David's choice of Jerusalem, a 'neutral location' (Breytenbach 1997:1171), as the site of the official cult, was a conciliatory venture to bring the north and the south into one royal household (2 Sam 5:1-11). After Solomon unity failed and Jerusalem functioned as the cultic center for the southern kingdom only. Jeroboam, ruler of the northern kingdom, was immediately advised to choose 'Shechem in the hill country of Ephraim', then Peniel and finally Bethel as residential and cultic sites (1 Ki 12:25-33 - a passage colored by a 'southern' bias). These sites were chosen because of ancient traditions concerning Abram (Gen 12:6) and Jacob (Gen 32:31), and the settlement of the descendants of Joseph respectivly. According to the northern tribes Joseph was the legitimate successor to lead the house of Abraham and Jacob in the center of the land. The bias of the editorial re-interpretation by Judean priests of the Bethel tradition, as if it were inherently defiled by pagan syncretism, should not be overlooked by a naive reading of the above-mentioned references in the First Testament. The domination of the Jerusalem temple cult should also be judged in the light of prophetic protests ${ }^{4}$.

However, in the period subsequent to the exile priestly elites continued with the process of ostracizing. This can be seen for example in the command the priests authorized as the 'law of God', that the 'men of Judah and Benjamin' must divorce their 'foreign spouses' and abandon the children born of such allegedly illegitimate marriages (Ezra 10; Neh 13:23-28). 1 and 2 Chronicles also try to restore the role of the monarchy and its priestly retainers. But according to Ezekiel (11:14-21; 33:23-26) the Israelites who were not exiled represent the people to whom God's promise made to Abraham applies. However, one reads in the version of 2 Chronicles (36:17-20) that nobody among God's people was spared by Nebuchadnezzar and, subsequently, no 'true believer' could possibly be found in Jerusalem or Judea - 'the land enjoyed its sabbath rests' until God made the king of Persia return God's people to re-established the cult in Jerusalem (2 Chron 36:21-23). Supported by birth records in the books Ezra and Nehemiah the returning exiles were designated as the 'true' and 'pure' inheritors of the land. Over against this claim one reads in 2 Kings 25:12, deliberately changed by priestly writers (2 Chron 36:17-20), that peasants, 'some of the poorest people of the land', were left behind in Judea by the commander of Nebuchadnezzar's imperial guard 
'to work the vineyards and fields'. This positive attitude towards the weak is also to be found in the period prior to the Davidic dynasty and the establishment of the temple in Jerualem. At the consummation of the period of the judges, Hannah's hymnal prayer (1 Sam 2:1-10) also attested to both God's ubiquitous sovereignty and God's act of humbling patrons and exalting clients. The backround of Hannah's prayer is both her presence as a woman in the shrine at Siloh (after she having given birth to the prophet Samuel who was miraculously conceived) and the references in the texts to the exploitative behavior of priests (Eli's sons) (1 Sam 1:21-28; 2:12-17).

\section{JOSEPH THE FOREFATHER OF THE SAMARITANS}

The history of Eli, the chief priest of the shrine at Siloh, ties in with our interest in the inter relatedness between Joseph the patriarch and the gospel traditions in the New Testament about Jesus son of Joseph, son of Eli (Lk 3:23). According to John's gospel the Pharisees belittled Jesus because Joseph's family was known to them (Jn 6:42). Their accusation is that Jesus is not a 'child of Abraham' as they are 'children of Abraham'; he, and not they, is therefore 'illegitimate' (Jn 8:42), a 'sinner' (Jn 9:16), a 'Samaritan' (Jn 8:48). The traditional Pharisaic version sees the origin of the Samaritans 'in the events related in 2 Kings 17' (Pummer 1987:3). According to this view the Samaritans were 'a mixture of pagans and inhabitants of the northern kingdom that had not been deported'. The Samaritans themselves, up to our times 5 , furiously deny this denunciation which had already became widespread during the first century $\mathbf{C}$ $\mathrm{E}$, as can specifically be seen in the work Antiquities by Flavius Josephus (see esp Egger 1986). By this time the Judeans' (and particularly the Jerusalemites') opposition to the Samaritans is 'clear and unequivocal' (see JosAnt xi, 96-97; Jn 4:9 - Coggins 1975:53). Pummer (1987:3) puts it as follows:

... [the] modern critical view ... recognizes that antagonism between north and south in Israel existed for many centuries, but it also realizes that there was no sudden break which brought the separation of Jews and Samaritans .... If one wants to name a definite date when the two communities began to exist as separate entities, it would be the end of the 2nd cent. B.C. when John Hyrcanus ${ }^{6}$ [captured Shechem ${ }^{7}$ and] destroyed the temple on Mt. Gerizim and the Samaritans in all probabality, like other groups [e.g. the Pharisees and the Essenes], began to adapt certain passages in the Pentateuch to their particular theology ${ }^{8}$. 
Today, research has establised the scholarly opinion that the 'Samaritans are associated not with Samaria but with Shechem' (Coggins 1975:9; Wright 1992:263-273). A more appropriate geographical designation used by Josephus for the people who generally came to be known as Samaritans is therefore 'Shechemites'9 (Montgomery 1968:70). According to Talmudic mentality the world was divided, in line with these categorizations: Judeans, Samaritans and Gentiles (Montgomery 1968:178). This particular division is also evident in Acts 1:8. Samaritans were considered to be 'mamzerim', that is people of uncertain parentage (Montgomery 1968:181), in other words illegitimate. In the Talmudic Tractate Kiddushin 75a (cf. Mass Kut 27) they were treated as bastards (Montgomery 1968:180-181). In like terms a Mishna qualifies the status of the Samaritans with respect to marriage arrangements of the Jerusalem cult: 'They are the people of uncertain condition [i.e. with whom one may not marry]: those of unknown parentage, foundlings, and Samaritans' 10 .

The Johannine report (4:1-26) of Jesus talking to the Samaritan woman at 'Jacob's well' is all but an innocent tale. The well is situated on the plot of the land 'Jacob had given to his son Joseph'. The land is near the Samaritan town Sychar. From this well 'our father Jacob' drank', as did 'his sons'. Here again we have an indication of the dualistic Johannine mentality: the 'physical' Joseph and his ancestors drink the 'physical' water from the well; and then there is the 'spiritual' son of Joseph, Jesus, who gives the water of eternal life. Furthermore, the fact that the story pertains to a Samaritan woman is particularly striking ${ }^{11}$. The notation of Sychar in the abovementioned Johannine story is understood by Eusebius and Jerome to be the site of the ancient Shechem (Montgomery 1968:19-21), close to the present-day Samaritan village Nablus ${ }^{12}$.

According to a relatively correct interpretation of available textual evidence in the First Testament, Priest Hasanein Wasef Kahen of the Samaritan Community in Nablus explained in 1966 that the establishing of the Judean cult in Jerusalem was the result of a wrong political evaluation. 'King Daoud who is the descendent of Yahuda tribe moved the capital to Jerusalem instead of Nablus' (Kahen 1966:8). David thought that building the capital of a united kingdom in a neutral place and not at 'the political and religious capital of the kingdom - Nablus - could contribute to supervising successfully all parts of the kingdom'. After that Solomon erected the temple in Jerusalem. This temple was 'build by human hands' (see the tradition used in Stephen's speech in Acts 7:48-49), while God's tent, the tabernacle was stil 'erected ... on a big rock that can be seen in Gerizim mountain until now' (Kahen 1966:5).

In agreement with the Samaritan Book of Joshua in Arabic (chapter 43 - cf Coggins 1975:122, retold slightly differently by representatives of the present-day Samaritan community in Nablus in Jordan, the Samaritans consider themselves as 'original Israelites whom the Jews split off in a schism under Eli who moved the ark of 
the covenant from Shechem to Shiloh' (Pummer 1987:3). They claim to be descendants of Ephraim and Manasseh, sons of Joseph born in Egypt. The mother of Ephraim and Manasseh is Asenath, the gentile daughter of the Egyptian Potiphera (Gen 42:50), priest at Heliopolis (On). Manasseh and Ephraim are the children God gave to Joseph and they were, according to Genesis 48:1-21, legitimized by the head of the covenantal family, Jacob (Israel), in terms of a near-Eastern judicial practice.

Over against the claim that Jerusalem is the 'city of David', the Johannine school knew the ancient northern tradition that the nascence of the messiah, son of David, should rather be sought at Rachel' tomb at Ephrat (Bethlehem) where Rachel (Jacob's wife and mother of Joseph) died during Jacob's journey from Bethel. Like father like son, like Joseph the patriarch, victim of slander, being rejected by his own people, sold for forty pieces of gold, but exalted over all the Egyptians at the age of thirty (Gen 41:46), Joseph's son, Jesus of Nazareth, was hated by the Judeans and belittled as demon-posessed, a sinner, a Samaritan, an illegitimate person. But like father like son, like Joseph the patriarch who became an example of compassion and one who forgave and loved his brothers (Gen 50:17), Jesus, in Johannine terms, loved the cosmos (= Judeans) despite its hate.

\section{JOSEPH THE FATHER OF JESUS}

Very few things that Joseph actively did are mentioned in the gospel tradition in the New Testament. The only things we read about are the reference to his rigtheousness, his Davidic ancestry, his dream and the angel's conversation with him, and his 'holy marriage' with the Mary (who stands in the line of the 'impure' women Tamar, Rahab, Ruth and Uriah's wife Bathsheba). In legendary fashion Matthew depicts Joseph as someone who took his family, Mary and the child Jesus, to Egypt. By means of a fulfillment formula, taken from the First Testament, Matthew (Mt 2:15) quotes the prophet Hosea $(11: 1)^{13}$ that God called back his child from Egypt to settle in Galilee. Galilee is referred to in Isaiah 9:1; 1 Maccabees 5:15 and Matthew 4:15 as 'Galilee where the heathens live'.

An attempt by the 'king of the Judeans', Herod the Great who himself is ironically from 'bastard' background, to kill the 'newborn king' is described by Matthew (2:18) in terms of another fulfillment quotation taken from the prophet Jeremiah (Jer 31:15) ${ }^{14}$ : 'Rachel weeping for her children ... because they are no more.' The Gospel of Luke does not share this material peculiar to Matthew, but clearly has clearly knowledge of the tradition that Bethelehem is the location of the Joseph family. He also knows that the origin of the savior of all people, Judeans, Samaritans and Galileans alike, according to the prophets, is not to be sought in Jerusalem but in Bethlehem. When Luke in 
the speech of the 'Hellenist outsider' Stephen in Acts (7:55-56) draws an analogy between Stephen and Jesus by retelling the story of the patriarchs, research shows thai Luke is dependant not on the Judean (Masoretic) but on the Samaritan Pentateuch (see Scobie 1973:393-396). In this speech (Acts 7:1-53) as well as the record about the 'Samaritan mission' headed by Philip (Acts 8:1-4) the controversy between the two tribes Judah and Joseph is to be read between the lines ${ }^{15}$.

Matthew's (also in other gospel traditions) notation of forgiving one's brother is one of the central characteristics of the portrayal of Jesus. The motive of compassion and forgiveness of sin by Joseph the patriarch is certainly the most outstanding theme in the intertestamental pseudepigraph The Testaments of the Twelve Patriarchs ${ }^{16}$. The gospel tradition in the New Testament shares and makes in striking ways use of this tradition in its depiction of Jesus. See, for example, Hollander (1981:65; my emphasis):

$\ldots$ it is the patriarch Joseph above all who plays a pre-eminent role in the ethics of the Testaments. Not only in his farewell-discourse is Joseph put forward as a good example for his sons, but his brothers too refer to him on their death-beds, exhorting their sons to be like Joseph. He was one who kept himself free from adultery, who never stopped loving his brothers, who was full of mercy, compassion and forgivingness, who humiliated himself. He was a righteous man tried by God and rewarded and exalted afterwards.

In the Testament of Benjamin (4:2) one reads (Hollander 1981:69-70): 'The good person has not a dark eye. For (s)he shows mercy to all people, even though they be sin-

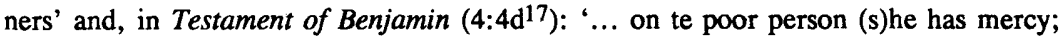
with the weak (s)he feels sympathy'. In the Testament of Zebulon (6:5; 7:3f) (Hollander 1981:73) the same attitude towards the poor and feeling of sympathy (in Greek: sumpathei) towards the weak is described as virtues of the patriarch Zebulon imitating the attitude and feeling of Joseph. In the Testament of Gad (4:1-2), in a passagge where Gad instructs his children, a very remarkable phrase appears which the gospel tradition in the New Testament attributes to Jesus: Gad reveals that 'lawlessness' against the Lord amounts to disobedience to the words of God's 'commandments concerning the love of one's neighbour, and its sins against God' (Sklar 1996:51). These instructions clearly go together with the confession of one's own sin and repentance and an ongoing forgiveness of the sin of others (see $T$ Gad 6:3-4, 7). 
Here we have a clear resemblance of the Matthean Jesus' words in the Lord's Prayer (Mt 6:12) and in the essence of the Ten Commandments (Mt 22:37-40). These words in the Testament of Gad refer to Gad's memory that Joseph wronged him several times. He also reminds himself of his bitter hatred towards Joseph so that he 'very often ... wanted to kill him' ( $T$ Gad 2:1), and his (and Judah's) own covetousness by selling Joseph for 'thirty pieces of gold' (cf T Gad 2:3-4).

From a reading of the Testaments of the Twelve Patriarchs powerful parallels between the Jesus of faith come to light, recorded in the gospel tradition, and Joseph the patriarch. An examples is for instance the references to Jesus' death on behalf of others. These deliberate resemblances, seen from another angle, should not surprise us. In the Testaments of the Twelve Patriarchs next generations are instructed to imitate 'our father Joseph'. It is therefore noteworthy, also with regard to the firstcentury Josephus, that the 'biblical Joseph's relationship with his brothers emerges as that part of the story which is most similar to Josephus' own life' (compare Jos $J A$ ii, 16) with Jos Vit 314, 306, 333, 389, 353 - cf Niehoff 1992:101).

In her work on The figure of Joseph in post-Biblical literature, Maren Niehoff (1992:52) finds: 'For one reason or another, Joseph seems to respresent for each narrator a certain Idealtyp.' The same is true with regard to Matthew's Joseph and the Joseph depicted in the romance Joseph and Asenath. Whereas the Testaments of the Twelve Patriarchs, in its present form, being dated in the second or third century C E but actually going back to probably the second century BCE Joseph and Asenath is being dated in the period between $100 \mathrm{BCE}$ and $115 \mathrm{CE}$ (Chesnutt 1996:286). The latter is a 'Hellenistic-Semitic' romance which focuses of God's intervention in the life of Joseph the patriarch (parallel to the Joseph in the gospel tradition) to take Asenath, an 'impure' woman, though a virgin, into his house. It is a story of a 'holy marriage'.

Most striking is the reference (JosAs [Ph] 15:7-8), in the so-called shorter constructed version of Marc Philonenko (1968), where Sophia is replaced by the figure Metanoia (referring to Aseneth): 'And Metanoia is a virgin, very beautiful and pure and chaste and gentle; and God Most High loves her, and all his angels do her reverence' (Standartinger 1996:309). Christoph Burchard's (1965) longer constructed version (JosAs 17:9 [B]), reads as follows: '(What a) foolish and bold (woman) I (am), because I have spoken with frankness and said that a man came into my chamber from heaven; and I did not know that (a) god came to me' (Standartinger 1995:311).

One has to keep in mind that Asenath's virginity is not mentioned in the Genesis account. However, both the fashion of Joseph's marriage to Asenath and her virginity were already in the first century CE widespread literary topics. For example, Josephus $(J A$ ii, 9), parallel to Joseph and Asenath, refers among others their 'most distinguished 
marriage' (in Greek: gamon axiologotaton) and Asenath's virginity (cf Niehoff 1992:106) ${ }^{18}$. This reference alone rules out the possibility that the author of Joseph and Asenath took this topic over from the evidence in the New Testament ${ }^{19}$. What is in all probability the case is that both the relevant tradition behind the gospel material in the New Testament and documents like Joseph and Asenath share a common idealization of Joseph's holy marriage. It is furthermore remarkable to notice that 'rabbinic Midrash is ... concerned with Asenath's alien origin and (that) this disturbing fact is accounted for in numerous ways' (Aptovitzer 1924:239-306; Niehoff 1992:107).

\section{CONCLUSION}

My concern in this paper is to focus on the references to the correspondences between father and son, between Joseph and Jesus. Actually, in this regard, it is highly problematic to refer to Joseph as the father of Jesus at all. These references do not occur in writings originating in the period before the beginning of the separation of the Pharasaic synagogue and the church after the destruction of Jerusalem in $70 \mathrm{CE}$ and the termination of the earliest Jerusalem church. It is clear that regarding the role which Joseph fulfills in the New Testament that there is an enormous distance between the historical Jesus tradition and the traditions in the gospels and post-New Testament documents (cf Oberlinner 1975:73-78). J P Meier (1991:317), in his A marginal Jew: Rethinking the historical Jesus, volume one: The roots of the problem and the person admitted that '.. the total silence about Joseph is significant'. However, he does not think that this gap is an 'unbridgeable gulf (Meier 1991:353 note 7). According to Meier there is 'converging evidence of the notable silences found in the Four Gospels and Acts, all of which have references to the mother and brothers (and sometimes the sisters)'.

For Meier (1991:317) the traditional solution, already known in the patristic period, remains the most likely. According to some church fathers Joseph was already dead when Jesus began acting in public. The first hint of this idea can be found in Proto-James. Here Joseph is portrayed as a very old man when he took Mary into his home. According to the church father Epiphanius (Panarion 3.78.10 - written ca 377 CE) Joseph died shortly after the family visited the temple in Jerusalem with the twelve-year old Jesus (as recorded by Luke 2:41-52) ${ }^{20}$.

However, I cannot see how Meier could seriously consider the patristic evidence as historically authentic. This evidence uncritically links Joseph's death with the episode of the twelve-year old Jesus in the temple. It is almost impossible to argue for the authenticity of this temple scene. Secondly, it is totally unthinkable in Mediterranean culture to tell a story of a man (in this case Jesus) without mentioning his father in 
some way or another. Meier (1991:317) quite correctly realizes that 'there is a completely neutral stance [of Joseph as father] toward Jesus' ministry'. However, it is less likely that this 'neutral stance' could be explained as due to the fact that it 'was of no symbolic use to the evangelists'. A male figure in the Mediterranean world without an explicit connection to his father, is someone without identity. It is comparable to a North American without a social security number or a South African without an identity number. Even today, when one crosses the border of an Arabic country like Jordan, one has to provide the name of one's father on the application form for a visa.

Meier (1991:353 note 5) is right when he argues that when Jesus mentioned a sister belonging to the household of God, he had his earthly relatives in mind. I find it difficult to see that the silence about his earthly father would imply that his father was already dead at that particular time. One would rather expect that, if Jesus used his earthly family as analogy for God's heavenly family, the role of the father would be important. Given the importance of the father in Mediterranean culture, how on earth would one cancel out the role of an earthly father?

In my view the other possible explanation to which Meier also refers, fits in better with the converging evidence in the relevant material closest to the historical Jesus: The father could have abandoned the family. It seems that the reason why he would do this, had to do with the conception of Jesus. Historically seen, we know nothing at all of the circumstances of Jesus' conception. Furthermore, there is no historical reason (including New Testament evidence - of Lk 2:721) why Jesus should be seen as the first-born. The suggested abandonment by the father could have had certain consequences that would conform with the information which we, in all probability, can discern historically:

* Jesus' tension with his family;

* Jesus' defence of the fatherless;

* Jesus' judgment of the abandonment of women (and children) by an act of divorce;

* Jesus' calling upon God as his father;

* Jesus' critique of the Jerusalemites;

* the absence of a family tomb as his last resting place.

Nonetheless, for other patristic fathers Joseph the 'woodworker' was stil 'deadly alive'. According to an expert among a previous generation of patristic scholars, A W Argyle (1956:199-202), one does not find references to Joseph, the First Testament patriarch in the prophets. However, as I have shown, the prophetic voice with regard 
to the conflict between the northern and southern kingdoms is very much embedded in the Joseph saga. For example, in Amos 6:1, 6 we read: 'Woe to you who are complacent in Zion, and to you who feel secure on Mount Samaria .... You drink wine by the bowfull ... but you do not grieve over the ruin of Joseph' [NIV] (see also Ezek 37:15-17). We also have seen that Joseph was more directly mentioned from the second century B C E onwards (see Wis 10:13f; Sir 49:15; 1 Macc 2:53; Jub 39-43; 1 En 89:13; JosAs; Testaments of the Twelve Patriarchs).

A similar pattern with regard to Joseph being simultaneously 'dead' and 'alive', can be found in both Judaism and Christianity. In Judaism Joseph became an ethical paradigm for repentance (see Schimmel 1981:60-65). An appeal to the example of Joseph also finds its way into Christian thinking. The First Testament saga of Joseph the patriarch provides an abundance of material for elaboration: he was 'a righteous man afflicted and sold by his brethren, steadfast in resisting temptation, unjustly accused, arrested, the benefactor of others, tender hearted, forgiving his brethren who had wronged him' (Argyle 1956:199).

The patristic fathers made use of this ethical paradigm in two ways: (1) as prefiguring the incarnation, passion, and exaltation of Jesus ${ }^{22},(2)$ as providing a model for Christian character and conduct ${ }^{23}$. The story of Joseph is therefore actually openended. In Christendom some think Joseph died early in Jesus' life. Others think he lives as an ethical symbol. To me it seems that it is highly probable that he should be regarded as a legendary figure.

My conclusion is that no known father played a role in the life of the historical Jesus. Such a conclusion has far reaching consequences for historical Jesus research. It seems that Joseph did not die early in Jesus' life, he actually entered the scene rather belatedly, at a time when Jesus was already crucified as a nobody and his corpse didn't find a resting place in a family tomb. For Greek speaking Israelites Joseph was an ethical paradigm. For Pharisees he was the symbolic adversary of Judah. For them he was the forefather of people who either came from the pagan world or mixed with them. In other words, the Joseph-people were regarded by the Judeans as bastards because they were a mixture of the children of God and gentiles, people who should be treated as if they have no parentage.

Who was first - the chicken or the egg? Who claimed first that the fatherless Jesus was the son of Joseph? Pharisees who regarded such a charge as a denotation of illegitimacy? Or Greek speaking Christians among the Israelites who regarded such a claim as a denotation of the intervention of God who turns slander into exaltation? We do not know. What we can say is that within Christendom the Joseph tradition clearly developed as a trajectory. This line of thought was impelled by the anti-Christian 
calumny against Mary and the associated evolution of the idea of the 'pure' (sinless) birth of Jesus. This idea led to the conviction that Mary remained a virgin after Jesus' birth, and even that she was herself the fruit of a 'divine birth'. However, there is no trace of a father who fulfilled a role in Jesus' life in historical Jesus material. For Jesus, God filled this emptiness.

\section{End Notes}

1 Other examples of similar analogies are John's comparisons of physical birth with spiritual birth (Jn 3:6), natural water and bread with water and bread that bring eternal life about (Jn 4:13; 6:27), worshipping God either in Jerusalem or on the Gerizim mountain in Samaria with worshipping God 'in spirit and in truth' (Jn 4:21), resuscitation from 'natural sleep' with the resurrection from death (In 11:12).

2 Among the many publications available I have had make use of Hennecke ([1959] 1973:404417); Manns (1977:80-114); Robinson (1896); Schaberg (1993); Sellew (1997).

3 For the inter relatedness between the prophetic traditions in the First Testament and the Joseph trajectory I am specifically indebted to the research of my colleague at the University of Pretoria, Andries Breytenbach (1997a:513-528; 1997b:1161-1186). For an ingenious treatise on the Pentateuchal traditions with regard to the two settlements in the land of Canaan which explain both the occupations of the center of the land by the tribes Ephraim, Manasseh and Benjamin and the plain of Esdraelon in the north by the house of Makir, the adopted (grand)son of Joseph born in Egypt, see Michand 1976:77-135). Manasseh and Ephraim were born to Joseph by Asenath daughter of Potiphera, priest of Heliopolis (On) in Egypt (cf Gen 46:19). As Jacob legitimated Manasseh and Ephraim (Gen 48:8-12), Joseph did the same to Makir, the son of Manasseh who also was born in Egypt (cf Gen 50:23b).

4 The prophets brought the Judeans' attempt to ensconce God's sovereignty within the boundaries of Jerusalem as 'city of David' to light. They challenged the royal household in Jerusalem and its priestly retainers not to be instrumental to the ostracism of the opponents (for example, see Jer $11: 18-12: 6 ; 18: 18-23 ; 36: 5,19,26 ; 37: 11-38: 13$ - see Breytenbach 1997b:1172). According to the prophet Jeremiah (23:1-6; 33:14-26) a newborn Davidic king would reign righteously over both Israel and Judea in the period after the Babylonian exile. This prophetic voice seems to be ambivalent. Similar apparently conflicting announcements occur in the book of Micah (chapters 2-5). It simultaneously supports the continuance of the Davidic dynasty and criticizes the exploitation of the peasants by the elites. Ezekiel (37:15:25) prophesized in the same vein, using the metaphor of two tribal wood sticks.

5 See the booklets of Amram Ishak, Samaritan Priest and President of the Higher Community of the Samaritan Religion, The history and religion of the Samaritans (sine anno); and Hasanein Wasf Kahen, Priest of the Samaritan Community, Samaritan history, identity, religion and subdivisions, literature and social Status (1966). 
6 Josephus ( $A J$ xiii, $9.1 ; B J$ i, 22.6). These expansionist activities should not be seen as driven by orthodox zeal. For further military operations by Hyrcanus' sons Antigonus and Aristobulus not long before 107 BCE and that of the Hasmonean Alexander Jannaeus in 88 BCE, see Josephus ( $A J$ xiii, 10.1-3; $B J \mathrm{i}, 2.7$ ) and Josephus ( $A J$ xiii, 14.1-2; $B J \mathrm{i}, 4.4$ ) respectively (cf Montgomery 1968:79-81).

7 According to Montgomery (1968:79) this happen in the year 128 BCE. Josephus relates that John Hyrcanus crushed the 'Kuthean sect'. This expression was a very pejorative label for the Samaritans which refers back to the 'Judean' report in 2 Kings 17:24 that the king of. Assyria brought people from, among other pagan places, Babylon and Cuthah to dwell in Samaria to replace the people of Israel (cf Pummer 1987:3).

8 This development could explain the striking similarities between Samaritan beliefs and those of the Sadducees, the party which came forth from Hyrcanus' Maccabean family. The 'close relationship in theology and practice of the Samaritans with the later Sadducees, who were the party of the hierarchy, can best be explained by the supposition of the maintenance of intercourse between the priests of Jerusalem and of the Shechemites' (Montgomery 1968:72). To me, correspondences in this regard, like attesting to the five books of Moses as the only authoritative scriptures and denouncing the belief in resurrection, could rather be ascribed to the power of the stronger party to enforce conformation.

9 In the Wisdom of Jesus son of Sirach (50:25-26) the contempt for the Samaritans is clear: 'With two races in my soul vexed; and the third is no nation: with the dwellers of Seir and Philistia, and with the foolish race that sojourns in Shechem.' Likewise in the Testament of Levi (chapter 7): 'From this day will Shechem be called the City of Fools' (citations in Montgomery 1968:154-155; my emphasis). In Rabbinic literature a separate treatise is taken up in the Mishna, Masseket Kutim ('Tractate on the Samaritans'). In this regard one has to be reminded that the Talmuds of Babylon and Jerusalem and their additional clusters of Toseftas originated over a long period of time. But it is also acknowledged that some traditions go back to the period of formative Judaism during the time of the New Testament.

10 The Gemara [Nidda 74b] likewise classes the sect amongst those peoples (the Ammonites, Moabites, Egyptians, Edomites and Nethinim [eunuchs, i.e. Jescendents of the ancient templeslaves]) whom priests are forbidden to marry. If the regulation of Deuteronomy 23:3-5 was followed, the Samaritans could not hope to marry Judeans until the tenth generation (which is practically indefinite). This application is actually made in Kiddushin $75^{\mathrm{a}}$.

11 It is possible that the words 'Judeans do not associate with Samaritans' (Jn 4:9) could be an euphemism for intermarriage. Of the 'principal points in which Judaism condemned the Samaritans, there is none more important and significant than its attitude towards women (cf Montgomery 1968:179). It capitalizes specifically on sexual matters. For example, Nidda (iv, i) imbues a spirit that could throw light light on Jesus' healing, probably authentic, of the suffering woman who had been bleeding for twelve years (cf Mk 5:25-29; Lk 8:43-48; Mt 9:20-24): 'The Samaritan women are menstruous from the cradle.' 
12 The ancient Shechem is today called Tell Balatah. The present-day Samaritan community in Nablus likes to identify their residential town Nablus near the Gerizim mountain with old Shechem (Kahen 1996:8; Ishak s a:23). Nablus is the modern name of the city Neapolis ('New City') which the emperor Vespasian founded but which the Roman writer Pliny' (His nat v, 14) assigned to a place originally called Mabartha. The ancient mosaic map of Madaba (in modern Jordan) also distinguishes between Neapolis and Shechem. Sychar (Jn 4:5) itself has now come to be identified with Ain Askar which lies 1250 meters north-east of Jacob's Well. However, the ruins of Nablus extend a distance east of the modern town. It could be that, because of textcorruption in the Gospel of John, Shechem, that is Nablus, accidentally became Sychar (Montgommery 1968:21). In John's gospel, as in the case of Luke-Acts, we have the allusion to the Judean division of the world in Judea, Samaria and Galilee/Gentiles. A clear-cut distinction between Jenusalem and Sychar (Shechem) is made in the story line of the first five chapters of the gospel.

13 Remember Hosea's connection with the Joseph tradition in terms of his marriage to an impure woman so that God sovereignty to act outside the conventional cultic structures could be proclaimed.

14 Remember the context within which the prophet argues, while holding onto the importance of the Davidic household, he nevertheless expects a totally new beginning in order to make an end to the atrocities of the royalties and their priestly retainers.

15 Whatever the origin of the Stephen-Philip group could be, they clearly did not share the view of the majority of Judeans that the Samaritans were descendants of foreigners who settled in the North after the fall of Samaria and that the 'true' Ten Tribes were still in exile in some far distant land. The Samaritan mission implies an acceptance of the Samaritans as part of God's people (as the Samaritans themselves have always maintained). Perhaps the Stephen-Philip group had in mind the great prophetic hopes (Jeremiah, Ezekiel, Zechariah) for a reunion of North and South - now that the new age had dawned, the time for such a reunion had come (Scobie 1973:399400).

16 Cf Hollander (1981); Sklar (1996); Zerbe (1993); Argyle (1951-2:256-258).

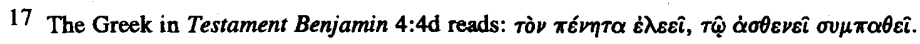

18 Niehoff (1992:107) refers also to Philo's knowledge of the 'marriage as a social distinction'.

19 However, there are New Testament scholars who regard both the Testaments of the Twelve Patrarchs and Joseph and Asenath as totally or to a great extent dependent on the New Testament. With regard to the Testaments of the Twelve Patriarchs, see especially De Jonge (1975:96-110) and with regard to Joseph and Asenath, see Price (1997). Over against De Jonge, Hollander (1981:10 would argue that the Testaments 'are certainly not a Christian composition'. However, it does not mean that I deny any Christian interpolation at all. The reference in the Testament of Joseph to the 'lamb of God', born from a virgin who takes away the 'sin of the world' is in all 
probablity such an interpolation. Yet a case for total dependence on the New Testament is not really convincing. Arguments will take us on a road where a set of complicated issues should be argued concerning intra-canonical relatedness, the order of passages caused by editorial activity, probable and less probable hypotheses regarding dates of documents, of the clustering of "canonical' groups of literature and locations of the audiences of these documents and corpuses of documents in order to expect knowledge thereof et cetera. For now I shall not travel along this path.

20 Cf Bertrand (1955:141-174; 1956:325-357; 1957:125-167, 289-320; 1958:139-179, 265-321; 1959:151-172, 275-333; 1960:171-186, 347-374; 1961:333-357; 1962:149-182). See Meier (1991:353 note 6).

21 William Whiston ([1960] 1978:415), the translator of Josephus' works, refers in a footnote to Izates, the 'only-begotten' son of Helena, the queen of Adiabene, as the 'one best-beloved': 'Josephus here [Ant. xx.ii.1] uses the word monogene, as only-begotten son, for no other than one best-beloved, as does both the Old and the New Testament; I mean where there were one or more

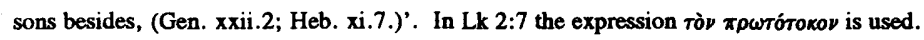

22 For Joseph as prototype of Jesus, see e g Justin Martyr, Dial c Trypho 36; Tertullian, Adv Marcionem iii, 18; Adv Judeaos 10; Origen, in Genesim, Hom XV; Cyprian, Liber de bono patientiae [Migne, P L, iv. col. 652-653; Jerome, Ep ad Riparium presbyterum, n 2 [P L, xxii, col 908]; Chrysostom, in Gen 37, Hom lxi [P G, liv. col. 528; Hom lxxxiv., Mt 26:51-54]; Ambrose, De Joseph Patriarcha, 14 [P L, xiv. col. 646]; Augustine, Ep Cl, iii. c. 39 [P L, xxxiii. col. 919]; Quaest in Heptat, cxlviii [P L, xxxiv. col. 588]; Cyril of Alexandria (see P G, 1xix. col. 376); Bede, In Pentateuchum Commentarii Gen 37-38 [P L, xci. col. 265-266].

23 For Joseph as an allegory of Christian conduct, see e.g., Athanasius, Apologia ad Constantium Imp, 12 [P G, xxv. col. 609]; Gregoryy of Nyssa, Contra Fornicarios [P G, xlvi. col. 493f.]; St Basil, Sermo xix (De Temperantia et Incontinentia [P G, xxxii. col. 1348]; Epistles, ii; xlvi (Epistolarum Classis, i.); Cyprian, Ad Fortunatum de Martyrio [P.L., iv. col. 693]; Liber de zelo et livore [P.L., iv. col. 666]; Chrysostom, Hom, Ixiv, Gen 41:46-49, n. 7; Bede, In Marci Evangelium Exposito, Lib. iv. [P L, xcii. col. 279].

\section{Works consulted}

Argyle, A W 1951-2. The influence of the Testaments of the Twelve Patriarchs upon the New Testament. Expository Times 63, 256-258.

1956. Joseph the patriarch in patristic teaching. Expository Times 199-202.

Aptovitzer, V 1924. Asenath, the wife of Joseph. Hebrew Union College Annual 1, 
239-306.

Bertrand, F-G \& Ponton, G 1955. Textes patristique sur saint Joseph. Cahiers de Joséphologie 3, 141-174.

1956. Textes patristique sur saint Joseph. Cahiers de Joséphologie 4, 325357.

- 1957. Textes patristique sur saint Joseph. Cahiers de Joséphologie 5, 125 167, 289-320.

1958. Textes patristique sur saint Joseph. Cahiers de Joséphologie 6, 139179, 265-321.

- 1959. Textes patristique sur saint Joseph. Cahiers de Joséphologie 7, 151172, 275-333.

1960. Textes patristique sur saint Joseph. Cahiers de Joséphologie 8, 171186, 347-374.

- 1961. Textes patristique sur saint Joseph. Cahiers de Joséphologie 9, 333357.

- 1962. Textes patristique sur saint Joseph. Cahiers de Joséphologie 10, 149182.

Bible (the Holy) [1973] 1984. New International Version. Grand Rapids, MI: Zondervan Publishing House.

Breytenbach, A P B 1997a. Die herfsfees en die koningsrite by Bet-El as interteks van Amos 7:10-8:14 en Hosea 9:1-9. HTS 53/3, 513-528.

- 1997b. Meesternarratiewe, kontranarratiew en kanonisering: 'n Perspektief op sommige profetiese geskrifte. HTS 53/4, 1161-1186.

Burchard, C 1965. Untersuchungen zu Joseph und Aseneth: ÜberlieferungOrtbestimmung. Tübingen: Mohr. (WUNT 8.)

Chesnutt, R D 1996. From text to context: The social matrix of Joseph and Aseneth, in Society of Biblical Literature 1996 Seminar Papers, 285-302. Atlanta: Scholars Press.

Coggins, R J 1975. Samaritans and Jews: The origins of Samaritanism reconsidered. Atlanta: John Knox Press.

De Jonge, M J 1975. The Testaments of the Twelve Patriarchs: A study of their text, composition and origin. Assen.

Egger, E 1986. Josephus Flavius und die Samaritaner: Eine terminologische Untersuchung zur Identitätsklärung der Samaritaner. Freiburg (Schweiz): Universitätsverlag/Göttingen: Vandenhoeck \& Ruprecht. (Novum Testamentum et Orbis Antiquus.) 
Grant, F C 1956. The economic background of the New Testament, in Davis, W D \& Daube, D (eds), The background of the New Testament and its eschatology: In honour of Charles Harold Dodd, 96-114. Cambridge: Cambridge University Press.

Hennecke, E [1959] 1973. New Testament Apocrypha, vol 1: Gospels and related writings, ed by W Schneemelcher and tr by R McL Wilson. Cambridge/Louis-ville, Kentucky: Clarke/Westminister John Knox.

Hollander, H W 1981. Joseph as an ethical model in the Testaments of the Twelve Patriarchs. Leiden: Brill. (Studia in Veteris Testamenti Pseudepigrapha.)

Ishak, A (Samaritan Priest and President of the Higher Community of the Samaritan Religion) sine anno. The history and religion of the Samaritans. Jerusalem: Greek Convent Press.

Kahen, H W (Priest of the Samaritan Community) 1966. Samaritan history, identity, religion and subdivisions, literature and social status. Jerusalem: Greek Convent Press.

Manns, F 1977. Essais sur le Judéo-Christianisme. Jerusalem: Franciscan Printing Press. (Studium Biblicum Franciscanum Analecta 12.)

Meier, J P 1991. A marginal Jew: Rethinking the historical Jesus, Volume one: The roots of the problem and the person. New York: Doubleday.

Michaud, R 1976. L'Histoire de Joseph, le Makirite (Genèse 37-50). Paris: Les éditions du Cerf.

Montgomery, J A [1907] 1968. The Samaritans: The earliest Jewish sect. Their history, theology and literature, with introduction by A S Halkin. New York: KTAV Publishing House.

Niehoff, M 1992. The figure of Joseph in post-Biblical Jewish literature. Leiden: Brill. (Arbeiten zur Geschichte ds Antiken Judentums und des Urchristentums 16.)

Oberlinner, L 1975. Historische Überliefering und christologisch Aussage. Stuttgart: KBW. (FB 19.)

Pilonenko, M 1968. Joseph et Aséneth: Introduction, texte critique en notes. Leiden: Brill. (SPB 13.)

Price, R M 1997. Implied reader response and the evolution of genres: Transitional stages between the ancient novels and Apocryphal Acts. HTS 53/4, 909-938.

Pummer, R 1987. The Samaritans. Leiden: Brill. (Iconography of Religions 23,5.)

Robinson, F 1896. Coptic apocryphal gospels: Translations together with the texts of some of them, in Robinson, J Armitage, Texts and studies: Contributions to biblical and patristic literature. Cambridge: University Press.

Schaberg, J 1993. The infancy of Mary of Nazareth (Proto-James and PseudoMatthew), in Schüssler Fiorenza, E. (ed), For searching the scriptures. New York: Crossroad. 
Scobie, C H H 1973. The origins and development of Samaritan Christianity. NTS $19,390-414$.

Schimmel, S 1981. Joseph and his brothers: A paradigm for repentance. Judaic Studies, 60-65.

Sellew, P 1997. Heroic biography and the literary intent of the Protevangelium Jacobi. Unplubished paper presented at the Christian Apocrypha Section, Annual Meeting of the SBL, San Francisco, 25 November 1997.

Sklar, H W 1996. The fighter of horizons: The story of Joseph as a model for social and spiritual reconciliation. MA Thesis, Graduate Theological Union, Berkeley, CA.

Standartinger, A 1995. Das Frauenbild im Judentum der hellenistischen Zeit: Ein Beitrag anhand von 'Joseph \& Aseneth'. Leiden: Brill. (Arbeiten zur Geschichte des Antiken Judentums und des Urchristentums.)

Whiston, W [1960] 1978. Josephus complete works, tr by W Whiston and with a foreword by W Sanford. Grand Rapids: Kregel Publications.

Wright, G E [1962] 1992. The Samaritans at Shechem, in Dexinger, F \& Pummer, R (Hrsg), Die Samaritaner, 263-273. Darmstadt: Wissenschaftliche Buchgesellschaft. (Wege der Forschung 604.)

Zerbe, G M 1993. Non-retaliation in early Jewish and New Testament texts. Sheffield: JSOT Press. 